\title{
Spatial patterns of child health inequalities in the province of Punjab, Pakistan The advantages of GIS in data analysis
}

\author{
Kashif Ur-Rehman, Basel, Anna Zimmer, Bonn
}

\section{Introduction}

Poverty is a multidimensional issue which translates broadly into impairment of human well-being. The current understanding of poverty is accordingly broad, encompassing classical concerns like food, shelter, health care, and education as well as immaterial aspects, such as freedom of speech, emancipation of women, security, and empowerment (WORLD BANK 2000).

Among other deprivations, poverty in a complex way is a cause of high child mortality rates (FOOD AND Agriculture Organization of the United Nations - FAO 2002). Child health status reflects the degree of human development of the entire population as «no indicator captures the divergence in human development opportunity more powerfully than child mortality» (United Nations Organisation - UNO 2005: 4).

Child mortality is thus a long-established measure not only of child health, but also of the well-being of a society (CANADIAN INSTITUTE FOR HEALTH INFORMATION 2005).

In the overall context of the Millennium Development Goals, Pakistan recently embarked on an effort to collect data regarding crucial issues of human development. The surveys conducted under the Federal Bureau of Statistics (2001-2009) aimed at informing poverty reduction strategies as well as development plans.

Despite the high relevance of this indicator for human development, studies about child health in Pakistan are currently limited. One reason for this is the lack of data at fine resolution (below district level) which would allow identification of differentiated patterns of child health inequalities over space. This shortcoming can be bypassed with the help of Geographical Information Systems (GIS) (Epprecht \& HeInimann 2004). With GIS it is possible to map incidences of diseases, thereby contributing toward better planning and location of health infrastructure (SCHWEIKART \& KISTEMANN 2001). BUTSCH \& SAKDAPOLRAK (forthcoming) identify public health service providers' lack of adequate information as one of the main bottlenecks in securing access to health care, especially for the poor. The following article therefore argues that child health inequalities between different districts of Punjab can be addressed more effectively with the help of the methods presented.

Child health status shows highly differentiated patterns over space. The first objective of this study, therefore, is to visualize geographical patterns of child health in one particular region in Pakistan: Punjab. Considering that health status is related to different sets of socio-economic determinants, be these directly (such as nutrition, vaccination, sanitation, and sources of drinking water) or indirectly (maternal literacy and economic poverty), the second objective is to present spatial data of these factors. It was hoped that the degree of correlation between these sets of determinants and the health status of children would become clearer. The third objective is to create a map of child health status at below district level resolution using the aggregate value of the most important determinants of health. It was assumed that this map would highlight the hot spots of poor health in the region.

\section{Data and methodological approach}

\subsection{Data}

To assess the health status and the relationships between health and other socio-economic factors, this study uses data from four surveys carried through by the Federal Bureau of Statistics Office of Pakistan:

(1) Pakistan Social and Living Standards Measurement (PSLM) Survey 2004-05: In this survey, information was collected on education, health, household assets/amenities, and vaccination coverage.

(2) Household Integrated Economic Survey (HIES) 2004-05: This survey provides data on household income, sources of income, savings, liabilities, consumption expenditure, and consumption.

(3) Pakistan Demographic Survey (PDS) 2005: Presents important data on births, deaths, fertility, mortality, and the current rate of population growth.

(4) Multiple Indicator Cluster Survey (MICS) of Punjab (2004-05): Includes data on births, deaths, fertility, and mortality at province level.

The infant mortality rate (IMR) and under-five mortality rate (U5MR) are major indicators of child health conditions and have been chosen as markers of health status for this study. The IMR refers to the 
number of children who die before turning one per 1000 children. U5MR reflects the number of children who die before their fifth birthday per 1000 children. Additionally, the number of children under five who are malnourished has been included in this study. This reflects the strong influence that the nutritional status of children has on their health. The main source of data for IMR, U5MR and malnourished children under five is the Multiple Indicator Cluster Survey of Punjab. Three types of data have been used for estimating IMR and U5MR in this survey: (1) five year intervals for women aged 15-49, (2) the mean number of children ever born (MCEB) and (3) the proportion of child deaths to total female population at respective ages.

Regarding representation of poverty, two important steps were necessary: 1) estimation of the poverty line and 2) estimation of percentage of population below this line. There are many approaches towards establishing the poverty line (JAMAL 2007; Moser 2006; WORLD BANK 2009). The poverty line used in this study is the official poverty line of Pakistan. Here, households are classified as poor if they do not have sufficient income to support a consumption pattern of 2350 calories per adult equivalent per day and cover minimum non-food requirements. The main source of data for calculating the incidence of poverty is the Household Integrated Economic Survey (HIES) 2004-2005. The available data does not give insight into the degree or severity of poverty (Coudouel et al. 2002: 34ff.). It is also acknowledged that the multiple dimensions of poverty cannot be suitably represented by figures reflecting relative population numbers under an income-based poverty line (KANBUR \& SQUIRE 1999: 23). The basic data for the other main socio-economic determinants of child health, like percentages of diarrhea-affected children, vaccination coverage, adequate sanitation, and accessibility to improved sources of drinking water have been adapted and modified from Pakistan Living Standard Measurement (PSLM) 2004-05. Unfortunately, the data collected by PSLM does not follow international procedures and definitions set by UNITED Nations Children's Fund - UNICEF \& World Health Organization - WHO (2008: 6 ff.). The term «adequate sanitation» here therefore refers to flush toilets and non-flush toilets, including closed and ventilated improved pit latrines and service/bucket latrines. Inadequate sanitation refers to households with no toilets. The term «improved sources of drinking water» includes households with access to taps, hand or motor pumps and dug wells. No distinction is made here between covered and uncovered wells, an aspect which would have been worth paying attention to (United Nations ChiLdREn's Fund - UNICEF \& World Health Organization - WHO 2008: 22).
Definite figures on the literacy rate of married women are not available in PSLM 2004/05. Maternal literacy has therefore been estimated using available data in PSML 2004/05 on literacy of women 15 years and older.

The sample size of the PSLM consists of 76'520 households and is considered sufficiently large enough to produce reliable estimates at district level in all provinces of Pakistan. Indicators are presented disaggregated by province and district. This is the first time that a district level survey has been undertaken for the entire country. A detailed overview of the methodological approaches used for the socio-economic variables selected here are presented in the Pakistan Living Standard Measurement (PSLM) 2004-2005, annexure-II

\subsection{Methodological approach}

Methodically, this study was organized in three steps:

- In a first step, available related statistical data from different surveys were processed and geo-referenced. This resulted in a statistical and GIS database which can be modified and used for further research and for other maps on child health status and related factors.

- In a second step, interrelations between the variables were identified and visualized using the geostatistical database.

- In a third step, all related variables with strong correlation to health status were aggregated into one variable. The result of this step is a map at sub-district level.

To develop a statistical and GIS database for this study, the variables needed to be processed to make them suitable for spatial analysis. All indicators were weighted to allow ranking amongst districts. The district with the most negative values ranked at the bottom of the health status list, while the district with the most positive values came out tops. During the course of the study, all districts in the province of Punjab were geo-referenced and all statistical data was translated into GIS form. This led to a geo database suitable for spatial analysis (Fig. 1).

All maps presented herein were derived from this geo database. GIS based maps on each variable of health status and on each socio-economic variable with strong relation to the aggregated health status were generated in order to keep the relation between health status and its determinants transparent.

By using a linear regression model, correlations were calculated between all indicators. These indicators were divided in two main categories: health status and other socio-economic indicators: 


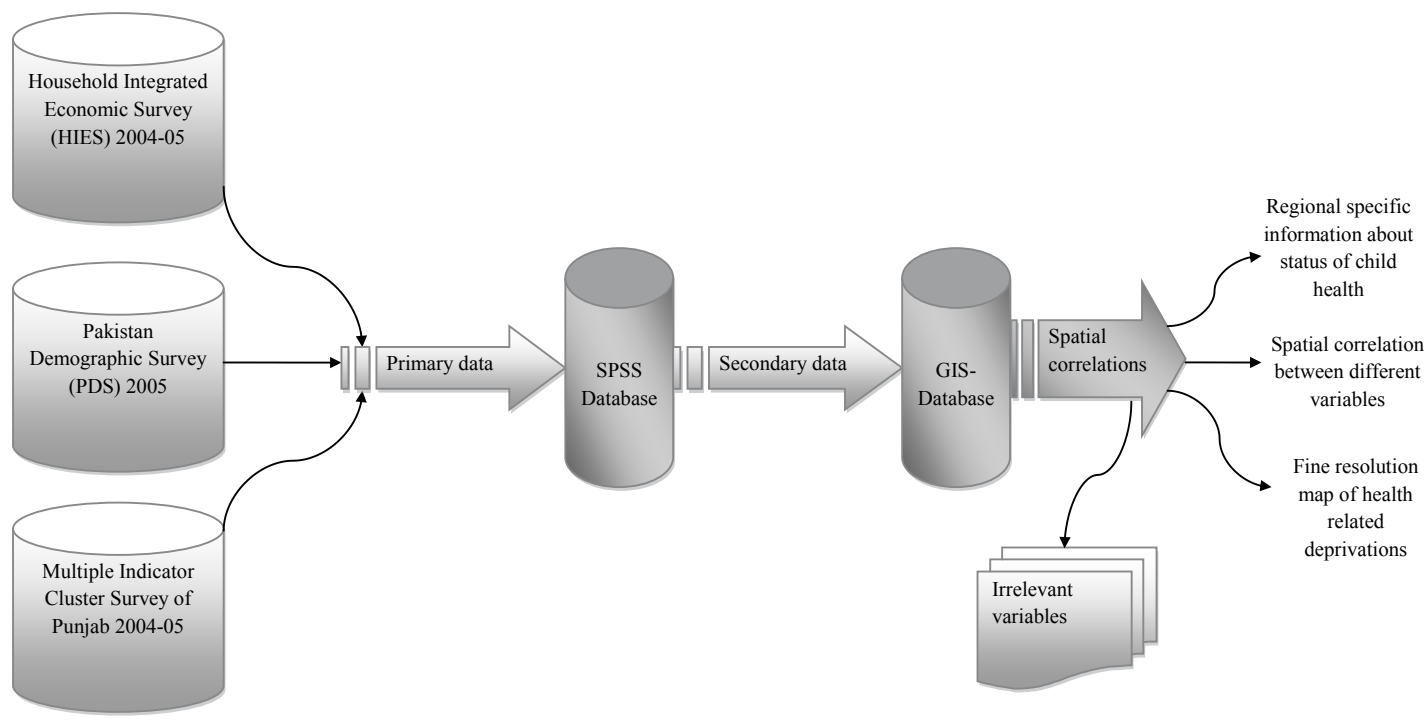

Fig. 1: Methodological steps involved in generation of suitable data for GIS maps on child health inequalities

Schritte der Datenverarbeitung in der Erstellung von GIS-Karten zum Gesundheitsstatus von Kindern

Etapes méthodologiques conduisant à la production de cartes SIG sur les inégalités de santé infantile

Geoprocessing by the authors

(1) As discussed above, health status reflects the combination of IMR, U5MR and percentage of children under five who are underweight. A very close correlation could be found between these variables of child health. Due to the close correlation, these three basic indicators were merged to one indicator, health status, allowing data reduction. The ranking of the districts according to health status thus reflects the sum of all three indicators. The district with the lowest total sum ranks at the bottom of the table while the district with the highest sum tops the ranking.

(2) All other socio-economic indicators like poverty, diarrhea, vaccination coverage, usage of Oral Rehydration Salts (ORS) against dehydration, adequate sanitation, accessibility to improved sources of drinking water, and mother literacy were not aggregated in order to keep their relation to health status transparent. After calculation of correlations, all variables with a strong relation $(\mathrm{r}$ $=$ higher than 0.5 ) to health status were aggregated using the same method as mentioned above. Variables with weak correlations were omitted in the further analysis.
Finally, the data on health status and on socio-economic determinants were aggregated together. On the base of the new aggregated indicator a map at fine resolution (see Figure 5) was developed using Arc GIS Geostatistical Analyst (ARc GIs 2001). Values for areas not recorded were estimated using the known values of surrounding areas. For this purpose, it was assumed that known values closest to those values being estimated have more influence on the results than those further away. Consequently, the points (the distance measurements were taken from the district centroid points) closer to the location of an estimated value are weighted more than those further away. Generally speaking, there are two significant drawbacks to using spatial regression models for calculating the spatial correlation: (1) the calculated spatial information between two points does not actually reflect the reality, and (2) due to spatial dependency and autocorrelation in the data, any error or misinformation in input data at one point has an influence on results of another point. For this reason, GIS Geostatistical Analyst offers six methods for interpolating spatial data. For this analysis, Inverse Distance Weighting (IDW) was chosen to support classification of areas of greatest concern below administrative boundaries. 


\section{Results and discussion}

Although figures for child health are worse in Pakistan than in any other South Asian country (GwATKIN et al. 2000), studies on infant and child mortality in this region are few (among others ARIF \& IBrahim 1998; MAHMOOD 2002). The national averages for IMR (73 per 1000 live births) and U5MR (94 per 1000 live births) are unacceptably high. In the case of Punjab, the IMR lies at 77 per 1000 live births and U5MR at 112 per 1000 live births. Thus, IMR and U5MR in Punjab are higher than the national average. Within Punjab, the districts of Rajanpur and Bhakhar (97), Muzaffar Garh (95), and Lodhran (93) are particularly hard hit concerning IMR. The latter three districts also have the highest U5MR.

The southwest of Punjab therefore appears to be a major area of concern in terms of health deprivations (see Fig.2).

As mentioned above, child health is strongly affected by nutritional status (HILl et al. 1999). Despite high IMR and U5MR, underweight prevalence in Pakistan is lower than in the other large South Asian countries (Bangladesh, India, Nepal). It is higher only in comparison with Bhutan and Sri Lanka. Still, considering the national average of $38 \%$, it is an aspect which should not be ignored. Punjab is slightly better off than the national average with $34 \%$ of children underweight. At district level, highest rates for underweight are found in the southwest with Bhakhar at $47 \%$, Rajanpur at $47 \%$, Muzaffar Garh at $46 \%$, D.G. Khan at $45 \%$, and Lodhran at $45 \%$ (see Fig. 2). These results on spatial distribution of underweight thus support other results that the southwest of Punjab is particularly affected by health inequalities (see chapter 3.2).

\subsection{Determinants of child health}

A good health status is the complex outcome of several structural factors, i.e. individual and household-related socio-economic determinants, as well as agency related factors, i.e. individual strategies to maintain health and cope with ill-health (BOHLE \& SAKDAPOLRAK 2009; NESTLE et al. 2007). Leaving aside agency related factors, which are best investigated with qualitative methods, the following sections describe spatial patterns in structural factors leading to unsatisfactory health outcomes. While «maternal literacy» reflects the education system, and «poverty» refers to economic factors, «water and sanitation» as well as «diarrhea» characterize the physical and infrastructural environment. «ORS therapy» and vaccination coverage are to be read as indicators of the quality of the health system.

\subsubsection{Maternal literacy}

The national average for maternal literacy in Pakistan is $36 \%$. For Punjab, the average is $40 \%$ and thus higher than in other provinces of Pakistan. Within Punjab, rates are worst in the northwest, with $18 \%$ in Lodhran, $20 \%$ in Mazaffar Garh, $25 \%$ in Rajan Pur, $26 \%$ in Bhakhar, and $26 \%$ in D.G. Khan.

Maternal education contributes to the reduction of child mortality in many ways: educated mothers, for example, tend to make use of prenatal care, get their children vaccinated (see 3.1.5) and are knowledgeable about better child care practices (BhUIYAT \& STREATfield 1991; Caldwell 1986; Hobcraft 1993; HosSEINPOOR 2005; TULASIDHAR 1993). The correlation of female literacy with health in this study is stronger than for all the other factors mentioned above $(\mathrm{r}=0.912)$. This strong correlation indicates that female literacy should be given maximum attention in state intervention with regard to child health. As it is assumed that educated women will pass their knowledge on to the next generation and are likely to give high priority to the education of their daughters, the education of women may be seen as a strong contribution towards forwarding development.

\subsubsection{Poverty}

The poverty line (see section 2.1) served for the estimation of poverty incidence. About $35 \%$ of the population of Pakistan lives below the poverty line. In the province of Punjab, the rate is slightly lower, with $32 \%$ living below the poverty line. However, within Punjab itself, striking differences exist: while the districts of Muzaffar Garh (56\%), Rajanpur (54\%), D.G. Khan (51\%), Lodhran (48\%), and Rahim yar Khan (46\%) show very high incidences of poverty, Rawalpindi (11\%), Lahore (12\%), Jehlum (12\%), Gujrat (13\%), and Sialkot (14\%) are far better off. The poverty map (see Fig. 3) helps to visualize these disparities, showing a clear prevalence of poverty in the southwest of Punjab.

Poverty can be clearly linked to health inequalities. In this study, there is a strong correlation between poverty and health status $(r=0.787)$. These results correspond with results from several studies, suggesting that there is a high correlation between poverty and child mortality (CALDWELL 1986; GWATKIN et al. 2000; WAGSTAFF 2002).

\subsubsection{Water and sanitation}

A better housing environment with safe drinking water und adequate sanitation is one of the major basic necessities for good health. Although infrastructure needs to be properly maintained if health is to benefit - a fact overlooked most of the times when setting political agendas (ZIMMER 2009) - the creation of facilities is a first step in the right direction. For this reason, attention is paid here to water and sanitation coverage (Fig. 4). 


\section{AFGHANISTAN}

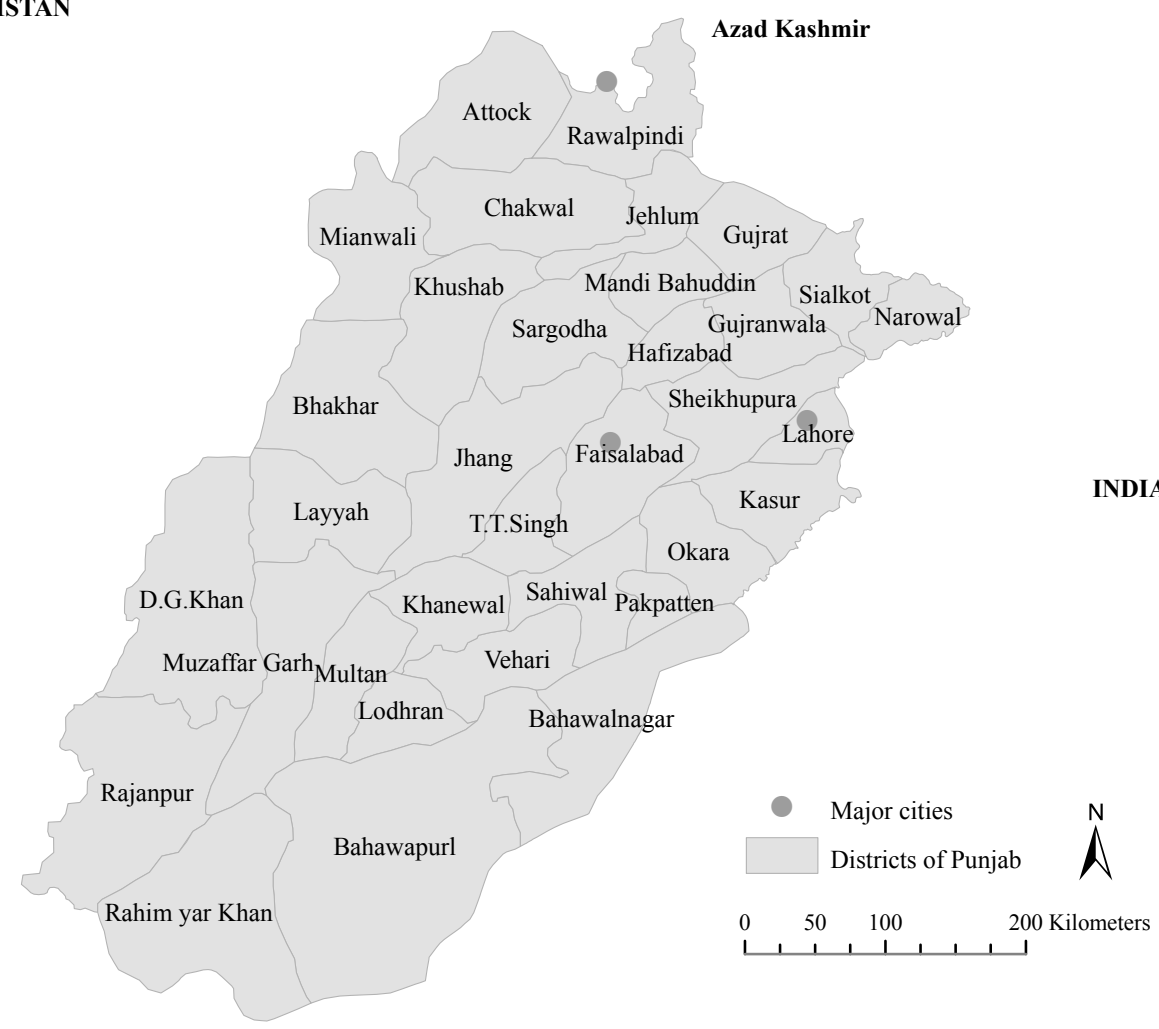

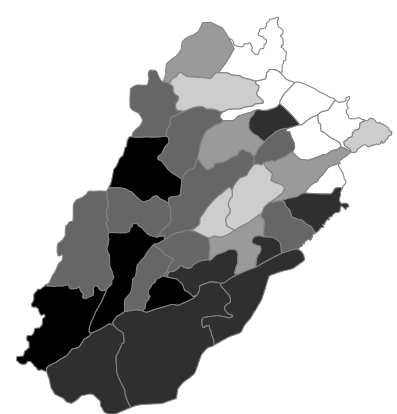

IMR (number of children per 1000 children, who die below one year of age)

6) तर को की की वर

$\left.5^{\prime} \Omega^{\prime}\right)^{\prime}$ \& $2^{\prime} 88^{\prime} a^{\prime}$

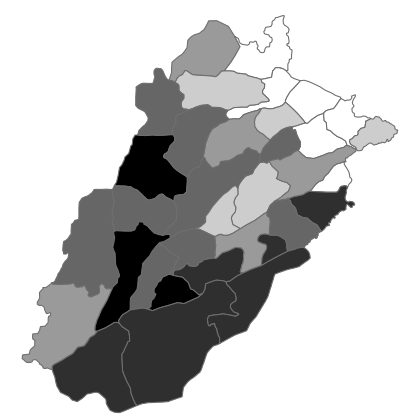

U5MR (number of children per 1000 children who die before their fifth birthday)

$$
9^{3}, v^{x}, 3^{6}+x^{3}, 5^{3}
$$

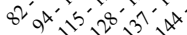

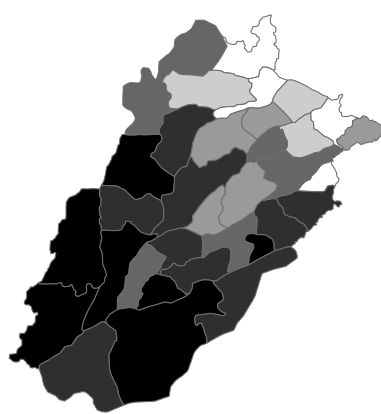

Under five years malnourished children in percent

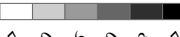

$\hat{\nu} 3^{0} 3^{0} x^{0} x^{3} \hat{x}$

$\nu^{\prime} \vartheta^{\prime} \boldsymbol{3}^{\prime} \hat{3}^{\prime} \alpha^{\prime \prime} x^{\prime \prime}$

$050100 \quad 200$ Kilometers L11,1

Fig. 2: Districts' locations and status of child health at district level in the province of Punjab, Pakistan Gesundheitsstatus von Kindern auf Distriktebene in der Provinz Punjab, Pakistan

Etat de santé des enfants à l'échelle des districts de la province du Punjab au Pakistan

Data source: Government of Pakistan (2005b), Pakistan Demographic Survey (PDS) 2005; Government of Punjab (2005), Multi Indicator Cluster Survey (MICS) Punjab 2004/05; Geoprocessing by the authors 


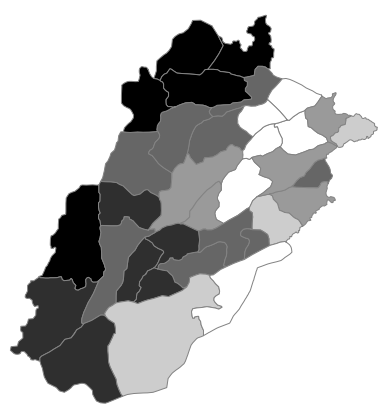

Percentage of children with treatment of diarrhea

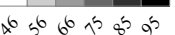
$3^{\circ} \hat{x}^{\prime} \hat{s}^{\prime} \hat{\sigma}^{\prime} 1^{\circ} 8^{\circ} 0^{\circ}$

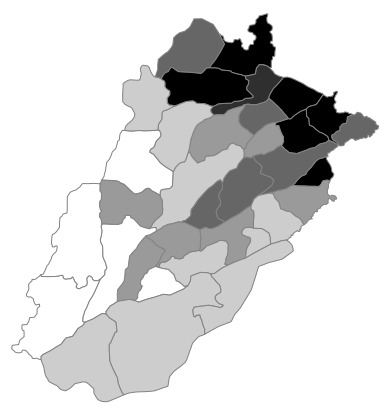

Maternal education (in percent)

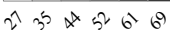
$10^{\prime} 2^{\prime} 3^{\circ} \times x^{\prime} 3^{\prime} \sigma^{\prime}$<smiles>NC1CC1</smiles>

050100200 Kilometers لــلـا

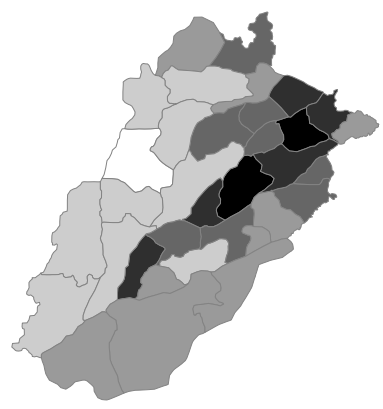

Percentage of households with adequate sanitation

$\hat{\imath} 3^{8} 5^{0} 6^{1} \hat{3}^{3 x}$

$\left.5^{\prime} 2^{\circ} 3^{\prime}\right)^{\prime} \sigma^{\prime} x^{x}$

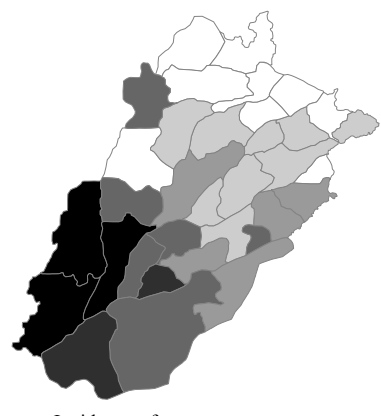

Incidence of poverty

(percentage of population below the poverty line)

$$
22^{0} 3^{x} x^{1} x^{2} 5^{6}
$$$$
120.23^{2} \times x^{2}=0^{2}
$$

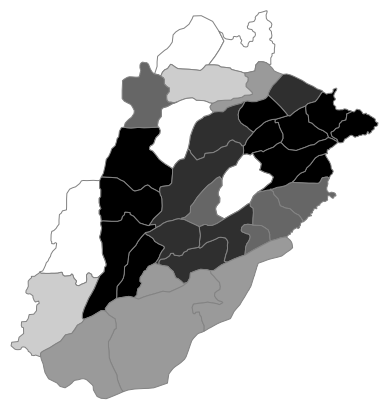

Percentage of households with improved source of water

$$
8^{1}, 8^{5}, 8^{2}, 0^{2}, 9^{6}, 0^{\circ}
$$

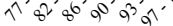
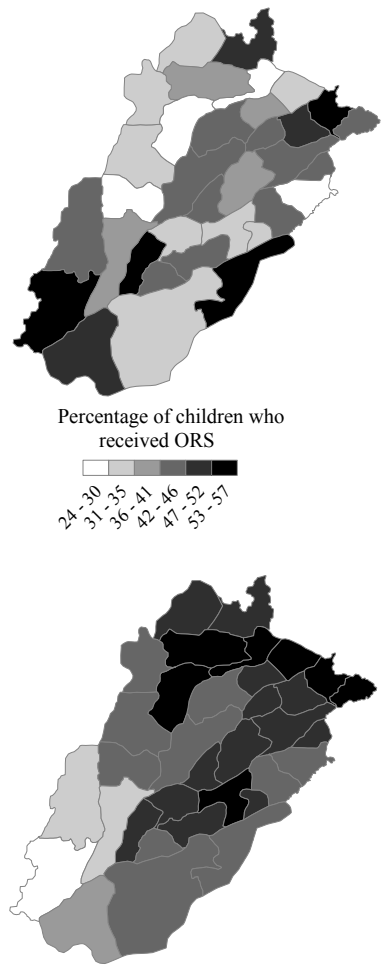

Immunization coverage (percentage of fully immunized children)

$$
3^{1} x^{3} 5^{5} 66^{6} 1^{8} 9^{0}
$$

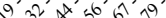

Fig. 3: Maps on all related variables at district level in the province of Punjab, Pakistan

Karten aller relevanten Variablen auf Distriktebene in der Provinz Punjab, Pakistan

Cartes des variables utilisées à l'échelle des districts de la province du Punjab au Pakistan

Data source: Government of Pakistan (2005a), Pakistan Social and Living Standards Measurement Survey (PSLM) 2004/05; Government of Pakistan (2005b), Pakistan Demographic Survey (PDS) 2005; Government of PunJab (2005), Multi Indicator Cluster Survey (MICS) Punjab 2004/05; Geoprocessing by the authors 


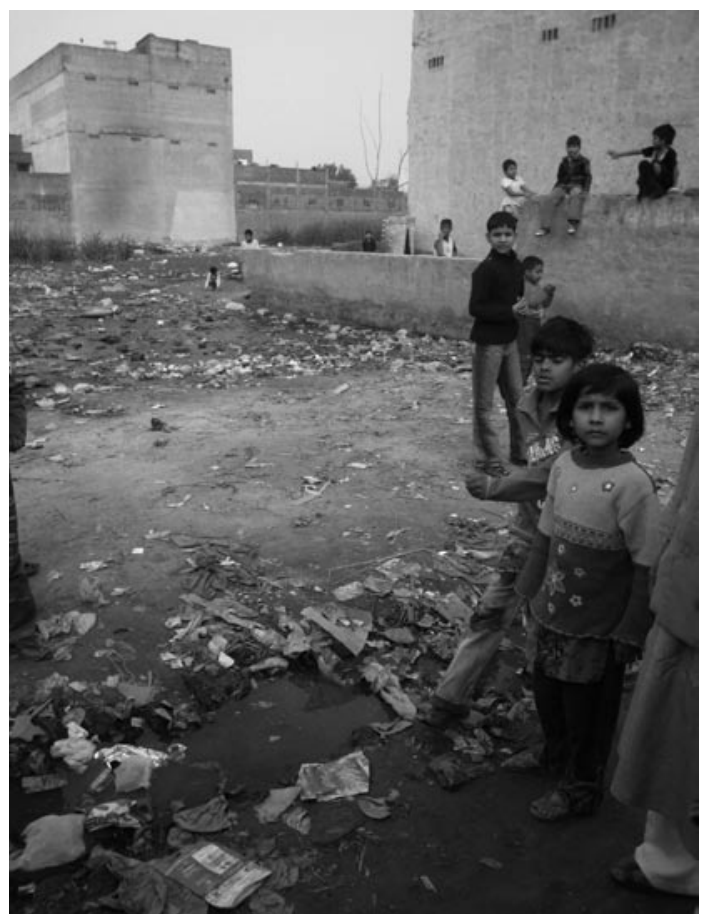

Fig. 4: Precarious status of sewage disposal Prekäre Verhältnisse in der Abwasserentsorgung La précarité des conditions d'évacuation des eaux usées

Foto: A. ZIMMER

Within Punjab, results show that access to improved sources of drinking water is lowest in the west and northwestern districts, namely Attock, Rawalpindi, and D.G. Khan, all of which have less than $80 \%$ of households with access to safe drinking water. These results correspond to diarrhea data, the incidence of diarrhea also being highest in the same districts. Regarding access to adequate sanitation the province is severely underserviced except in the northeast; particularly in the west, access rates of under $36 \%$ prevail, with only an alarming $15-22 \%$ of households in Bhakhar recorded as having adequate sanitation facilities.

The connection between water, sanitation, and health has been established time and again. An estimated $80 \%$ of sicknesses in the world are water-related (Black \& FAWCETT 2008: 71). However, in our study, the correlation between health and water supply is $r=$ 0.1 and health and diarrhea is $r=0.586$, which is well below expectations.
Possible reason for these results could be the different approaches used to determe sanitation categories between PSLM data and international studies and the lack of information about the quality of sanitation infrastructure. Infrastructure which is not properly maintained provides no benefit in terms of health outcomes. The results presented here on available water supply and sanitation does not reflect safe supply and disposal of water and waste water. Low correlations thus do not suggest that there is no relationship between health and water and sanitation. Rather, they highlight the need for inclusion of more meaningful data.

\subsubsection{Diarrhea and use of ORS therapy}

The nutritional status of a child is determined amongst other factors by the number of times it has had diarrhea (ARIF \& Ibrahim 1998; Mahmood 2003). Furthermore, acute diarrhea is one of the leading causes of death among children under five, with almost 2 million victims per year worldwide (UNITED NATIONS CHILDREN's FunD - UNICEF 2006). The main cause of death in these cases is dehydration. The percentage of children with dehydration caused by diarrhea in Pakistan in $2004-2005$ is $91 \%$. Of the country's four provinces, Punjab rates second best in this area with $90 \%$. Within Punjab, the northwest and western districts have the highest percentages of diarrheal induced dehydration: Attock (95\%), Rawalpindi (91\%), Chakwal (88\%), Mianwali (88\%), and D.G. Khan (87\%) (see Fig. 5). As correlation of diarrhea with child health status does not indicate a very strong relation $(r=0.110)$, it has been omitted from further analysis.

Dehydration can be prevented by the use of Oral Rehydration Therapy (BALTZAR et al. 2002; VICTORA et al. 2000). WHO and UNICEF recommend the use of Oral Rehydration Salts (ORS) to treat dehydration caused by diarrhea. In the case of Pakistan, the average percentage of children with diarrhea who received ORS is $78 \%$. However, the percentage for Punjab is lowest in the country with just $41 \%$. The spatial pattern of ORS coverage is not as clear as that of other health related parameters. Figures are highest in the southern districts of Multan, Rajanpur (both $57 \%$ ), as well as Bhawalnagar (55\%) and Rahim Yar Khan (51\%), but northern districts like Sialkot $(57 \%)$, Rawalpindi (50\%) and Gujranwala $(48 \%)$ fare almost equally well. In contrast, figures are low in the neighboring northern districts of Jehlum, Kashur, Layyah, Khushab and Mianwali (between 24\% and 29\%) (see Fig. 3). Correlation between ORS therapy and health status is weak ( $\mathrm{r}$ $=0.146$ ). Identifying the reason for this weak correlation would need further research and is not part of this study. Consequently, this factor was also discarded from further analysis. 


\begin{tabular}{|c|c|c|c|c|c|c|c|c|c|c|}
\hline & IMR & U5MR & $\begin{array}{l}\text { Malnourished } \\
\text { Childern }\end{array}$ & $\begin{array}{c}\text { Immunization } \\
\text { coverage }\end{array}$ & ORS & $\begin{array}{l}\text { Mother } \\
\text { education }\end{array}$ & Safe water & $\begin{array}{l}\text { Adequate } \\
\text { sanitation }\end{array}$ & Diarrhea & Poverty \\
\hline IMR & 1.000 & .856 & .916 & .703 & .103 & .867 & .109 & .568 & .059 & .730 \\
\hline U5MR & .856 & 1.000 & .933 & .679 & .197 & .858 & .130 & .528 & .084 & .742 \\
\hline $\begin{array}{l}\text { Malnourished } \\
\text { Chidern }\end{array}$ & .916 & .933 & 1.000 & .766 & .110 & .926 & .218 & .611 & .169 & .811 \\
\hline $\begin{array}{l}\text { Immunization } \\
\text { coverage }\end{array}$ & .703 & .679 & .766 & 1.000 & -.088 & .785 & .246 & .432 & .150 & .723 \\
\hline ORS & .103 & .197 & .110 & -.088 & 1.000 & .043 & .124 & .261 & .165 & -.075 \\
\hline $\begin{array}{l}\text { Mother } \\
\text { education }\end{array}$ & .867 & .858 & .926 & .785 & .043 & 1.000 & .255 & .661 & .239 & .830 \\
\hline Safe water & .109 & .130 & .218 & .246 & .124 & .255 & 1.000 & .281 & .491 & .169 \\
\hline $\begin{array}{l}\text { Adequate } \\
\text { sanitation }\end{array}$ & .568 & .528 & .611 & .432 & .261 & .661 & .281 & 1.000 & .456 & .391 \\
\hline Diarrhea & .059 & .084 & .169 & .150 & .165 & .239 & .491 & .456 & 1.000 & .193 \\
\hline Poverty & .730 & .742 & .811 & .723 & -.075 & .830 & .169 & .391 & .193 & 1.000 \\
\hline
\end{tabular}

Fig. 5: Correlations between IMR (number of children per 1000 children who die before their first birthday), U5MR (number of children per 1000 children who die before their fifth birthday), malnourishment (percentage of malnourished children under five), adequate sanitation, accessibility to improved sources of drinking water, poverty, mother literacy, ORS (Oral Rehydration Solution) therapies, diarrhea and vaccination coverage

Korrelation zwischen Gesundheitsstatus von Kindern und IMR (Anteil der Kinder pro 1000 Lebendgeburten, die vor Erreichen des 1. Lebensjahres sterben), U5MR (Anteil der Kinder pro 1000 Lebendgeburten, die vor Erreichen des 5. Lebensjahres sterben), Unterernährung (Prozentsatz mangelernährter Kinder unter fünf Jahren), angemessener sanitärer Versorgung, Zugang zu verbesserten Trinkwasserquellen, Armut, Bildung der Mütter, ORS (Oral Rehydration Solution)-Therapien, Durchfallerkrankungen und Anteil geimpfter Kinder

Corrélations entre les variables IMR (nombre d'enfants décédés avant leur premier anniversaire en pour mille), U5MR (nombre d'enfants décédés avant leur cinquième anniversaire en pour mille), malnutrition (pourcentage d'enfants de moins de cinq ans mal nourris), installations sanitaires adéquates, accessibilité à des sources d'eau potable améliorées, pauvreté, éducation de la mère, thérapies ORS (Oral Rehydration Solution), diarrhées et couverture vaccinale

Data source: Government of Pakistan (2005a), Pakistan Social and Living Standards Measurement Survey (PSLM) 2004/05; Government of Pakistan (2005b), Pakistan Demographic Survey (PDS) 2005; Government of PunJab (2005), Multi Indicator Cluster Survey (MICS) Punjab 2004/05

\subsubsection{Vaccination coverage}

WHO suggests children should be vaccinated in order to significantly reduce the risk of death in the first five years of life (UNITED NATIONS ChILdREN's Fund - UNICEF 2007). The recommended vaccinations are BCG (against tuberculosis), three doses of DPT (against diphtheria, pertussis and tetanus), three doses of polio vaccine and a measles vaccination. A child is considered fully vaccinated after receiving BCG, DTP1-3 and Polio 1-3.

About $49 \%$ children in Pakistan are fully vaccinated. The percentages for Punjab are by far the highest in the country (66\%). This may be connected to the high maternal literacy rates in the province (see 3.1.1). Yet, while values in the northern districts are high, critical rates are found in the southern districts of Rajan- pur (19\%), D.G. Khan (37\%), Muzaffar Garh (41\%), Rahim Yar Khan (43\%), and Lodhran (56\%). Correlation of vaccination coverage and health status is estimated at $r=0.736$. For this reason, vaccination status has been included in the further analysis.

\subsection{Aggregated map}

As may be seen in section 3.1, the data on maternal literacy, poverty and vaccination coverage proved to be the most relevant for determining the health status of children in the province of Punjab. As described in section 2.2, each of these parameters was aggregated in order to establish areas of greatest risk (see Fig. 6). The resulting map provides spatial information on child health inequality at district level and within each district across the province. 


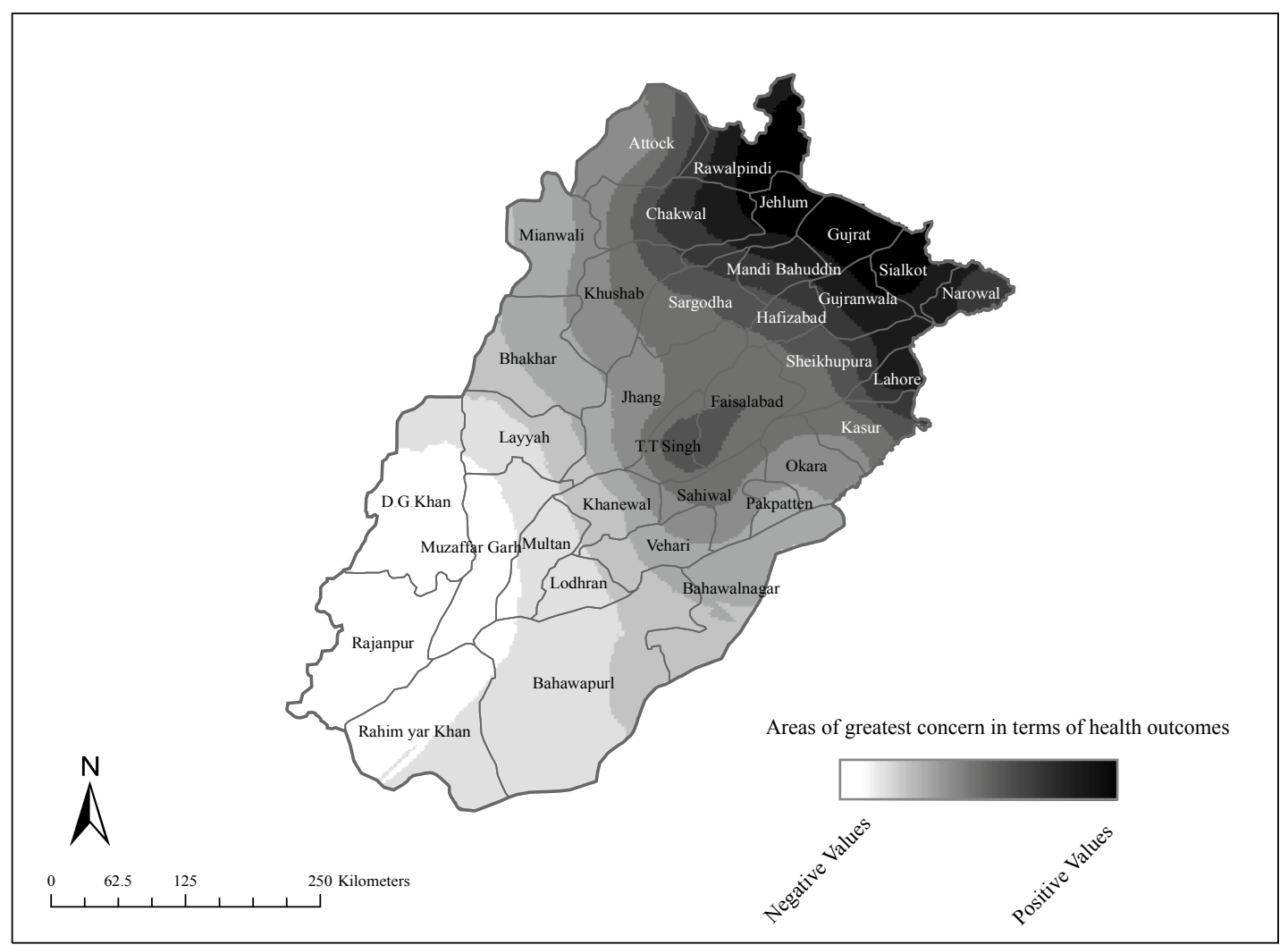

Fig. 6: Areas of greatest concern regarding child health status in the province of Punjab, Pakistan Problematischste Regionen in Bezug auf den Gesundheitsstatus von Kindern in der Provinz Punjab, Pakistan Régions dans lesquelles l'état de santé infantile est problématique dans la province du Punjab au Pakistan Data source: Government of Pakistan (2005a), Pakistan Social and Living Standards Measurement Survey (PSLM) 2004/05; Government of Pakistan (2005b), Pakistan Demographic Survey (PDS) 2005; GovernMent of PunJab (2005), Multi Indicator Cluster Survey (MICS) Punjab 2004/05; Geoprocessing by the authors

\section{Conclusion}

The presented data analysis allows a clear picture to be made of the status of child health in the province of Punjab. In particular, child health in southwest Punjab appears to be most at risk and requires special political attention.

Correlation analysis of socio-economic factors shows very close correlations between health and poverty, mother literacy, and vaccination coverage. By combining visualization techniques with statistical methods, underlying causes of health decline could be revealed. In the presented case study, female literacy was shown to be the single most important factor in enhancing child health, thus indicating options for possible policy interventions.
The aggregated map demonstrates how GIS can support policy makers to go beyond administrative boundaries in identifying ill-health hot spots. Although fine resolution data are not yet available, the approach makes patterns of socio-economic deprivation more visible, an aspect which may be useful for decision makers seeking to implement alleviation programs with more precise allocation of efforts and funds.

Further, the study reveals several other benefits of a GIS approach to analyzing health issues: Firstly, the maps of each variable selected for this analysis (see Fig. 2 and Fig. 3) make existing spatial patterns of inequalities clearly visible and provide information on background factors of child health inequali- 
ties. The data processed for these maps can also be used and modified for cognitive and monitoring purposes. In this way, a GIS approach allows easy comprehension of data and contributes towards closing the information gap in the health system (BuTsCH \& SAKDAPOLRAK forthcoming). When combined with statistical correlation it can help overcome narrow approaches towards issues such as health by allowing complex multiple dimensions to be included in the analysis.

Secondly, a GIS approach results in a more precise identification of areas of concern and allows for better planning of health infrastructure (SCHWEIKART \& KISTEMANN 2001). This could have an impact on health governance as government officials at district level and below would have access to necessary arguments for fund allocation. In this way, decentralized governance structures can be strengthened vis-à-vis higher levels of bureaucracy and government.

If the maps are made accessible to the citizens, they offer advantages beyond an «informing» of the public sector (BERNTZEN et al. 2005). Even if accessibility through the internet is restricted to certain social classes and groups (McCALL 2003), the visual aspect of mapping statistical data alone allows even poorly educated people to apprehend inequalities and monitor the outcomes of political initiatives more easily. GIS can therefore promote transparency if maps become devices of political activism and are used to hold the government accountable.

\section{References}

ARC GIS (2001): Using Arc GIS geostatistical analyst. - http://www.ci.uri.edu/projects/geostats/Using ArcGIS_Geostat_Anal_Tutor.pdf 01.07.2009.

ARIF, G.M. \& S. IBRAHIM (1998): Diarrhoea morbidity differentials among children in Pakistan. - http://ideas.repec. org/a/pid/journl/v37y1998i3p205-230.html 01.06.2009.

Baltzar, J., Nadera, P. \& G. Victora (2002): Evaluation of the national control of Diarrhoeal Disease Programme in the Philippines, 1980-93. - http://www.scielosp.org/pdf/bwho/v80n8/v80n8a07.pdf 22.09.2009.

Berntzen, L., Steinmann, R. \& A. Krek (2005): Innovative use of Geographic Information Systems to facilitate collaboration between the government and citizens. - http://www.salzburgresearch.at/research/gfx/ echallenges2005_ljubljana_final_7.pdf 03.02.2010.

BhuiYat, A. \& K. StreATFIELd (1991): Mothers' education and survival of female children in a rural area of Bangladesh. - In: Population Studies 45: 253-264.

BLACK, M. \& B. FAWCETT (2008): The last taboo. Opening the door on the global sanitation crisis. - London: Earthscan.
Bohle, H. \& P. SAKDAPolraK (2009): Chennai. Alltagskampf um Wasser, Nahrung und Gesundheit. - In: Geographie und Schule 31, 181: 4-10.

Butsch, C. \& P. SaKdapolraK (forthcoming): Geographien von Gesundheit in Schwellen- und Entwicklungsländern. - In: Geographische Rundschau.

CALDWELL, J.C. (1986): Routes to low mortality in poor countries. $-=$ Population and Development Review 12, New York: 171-220.

Canadian Institute for Health Information (2005): Health indicators. - http://secure.cihi.ca/indicators/2005/ en/hlthind05_e.shtml 27.11.2009.

Coudouel, A., Hentschel, J.S. \& Q.T. Wodon (2002): Poverty measurement and analysis. PRSP Sourcebook. - http://siteresources.worldbank.org/INTPRS1/ Resources/383606-1205334112622/5467_chap1.pdf 19.01.2010.

EPPRECht, M. \& A. HeInIMANN (2004): Socioeconomic atlas of Vietnam. - http://www.laoatlas.net/links/ PDF\%20download.html 29.09.2009.

Food and Agriculture Organization of the United NATIONS - FAO (2002): Food insecurity in the World. - http://www.fao.org/docrep/005/Y7352e/y7352e00. HTM 20.11.2009.

Government of Pakistan (2005a): Pakistan Social and Living Standards Measurement Survey. - Islamabad: Federal Bureau of Statistics.

Government of Pakistan (2005b): Pakistan Demographic Survey. - Islamabad: Federal Bureau of Statistics.

Government of Punjab (2005): Multiple Indicator Cluster Survey (MICS). - Lahore: Bureau of Statistics.

Gwatkin, D., Rutstein, S., Johnson, K., Suliman, E., Wagstaff, A. \& A. Amouzou (2000): Socioeconomic differences in health, nutrition and population. $-=$ World Bank Health, Nutrition and Population Discussion Paper 39437, Washington, D.C.: 1-79.

Hill, K., Pande, R., Mahy, M. \& G. Johnes (1999): Trends in child mortality in the developing world: 1960 to 1996. - New York: United Nations Children's Fund - UNICEF.

Hobcraft, J. (1993): Women's education, child welfare and child survival. A review of the evidence. - In: Health Transition Review 3, 2:159-173.

HosseINPOOR,A.R (2005): Socioeconomic inequalities in infant mortality in Iran and across its provinces. - http:// www.ncbi.nlm.nih.gov/pmc/articles/PMC2626462/ pdf/16302040.pdf 25.08.2009.

JAMAL, H. (2007): Updating poverty and inequality estimates. 2005 panorama. - http://www.spdc-pak.com/ pubs/rr/rr69.pdf 04.08.2009.

Kanbur, R. \& L. Squire. (1999): The evolution of thinking about poverty: Exploring the interactions. - http://siteresources.worldbank.org/INTPOVERTY/ Resources/WDR/evolut.pdf 19.01.2010.

MAHMOOD, A. (2003): Infant and child mortality esti- 
mates from Pakistan Population Census 1998. - Islamabad: Pakistan Institute of Development Economics. Marmood, A. (2002): Determinants of neo-natal and post no-natal mortality in Pakistan. - http://www.pide. org.pk/pdf/PDR/2002/Volume4/723-744.pdf 12.08.2009. MCCALL, M. (2003): Seeking good governance in participatory-GIS: a review of processes and governance dimensions in applying GIS to participatory spatial planning. - In: Habitat International 27, 4: 549-573.

Moser, C. (2006): Asset-based approaches to poverty reduction in a globalized context. - http://www.brookings.edu/views/papers/200611moser.pdf 20.11.2009

Nestle, M., Sakdapolrak, P., Bohle, H.G., Glaser, R., Louis, V., Mistelbacher, J., Sauerborn, R., Gans, P. \& M. LECHNER (2007): Umweltkrise und Gesundheitsrisiken in einer indischen Megacity. - In: Glaser, R. \& K. Kremb (eds). - Asien. Reihe Planet Erde, Darmstadt: Wissenschaftliche Buchgesellschaft: 209-214.

SchweIKART, J. \& T. KISTEMANN (2001): Geoinformationssysteme in der Medizinischen Geographie. - In: Petermanns Geographische Mitteilungen 145, 3: 1829.

Tulasidhar, V.B. (1993): Maternal education, female labour force participation and child mortality. Evidence from the Indian census. - In: Health Transition Review 3, 2: 177-190.

United NATIONs ChILdREN's Fund - UNICEF (2006): State of World's Children. - http://www.unicef.org/ pfo/files/2007_State_of_the_Worlds_Children.pdf 20.08.2009.

United Nations Children's Fund - UNICEF (2007): The State of the World's Children 2008: Child survival. -http://www.unicef.org/publications/index_42623.html 25.09.2009.

United Nations Children's Fund - UNICEF \& World Health Organization - WHO (2008): Progress on drinking water and sanitation. Special focus on sanitation. - New York, Geneva: WHO.

United Nations Organisation - UNO (2005): Human Development Report 2005. - http:/hdr.undp.org/en/ media/HDR05_complete.pdf 25.07.2009.

Victora, C., Bryce, J., Fontaine, O. \& R. Monasch (2000): Reducing deaths from diarrhoea through oral rehydration therapy. - http://www.ncbi.nlm.nih.gov/ pmc/articles/PMC2560623/?tool=pubmed 21.08.2009.

Wagstaff, A (2002): Poverty and health sector inequalities. - http://www.scielosp.org/pdf/bwho/v80n2/ a04v80n2.pdf 23.09.2009.

WORLD BANK (2000): World Development Report 2000/2001. - http://siteresources.worldbank.org/INTPOVERTY/Resources/WDR/English-Full-Text-Report/toc.pdf 21.07.2009.

WORLD BANK (2009): Handbook on poverty and inequality. - http://issuu.com/world.bank.publications/ docs/9780821376133 05.01.2010.

ZIMmer, A. (2009): Social relations in the waste waterscapes: the case of Delhi's informal settlements. - In:
UGEC Viewpoints 2009/09: 9-12; http://www.ugec.org/ tiki-index.php?page=ReportsNewsletters 01.11.2009.

\section{Abstract: Spatial patterns of child health inequalities in the province of Punjab, Pakistan. The advantages of GIS in data analysis}

In the overall context of the Millennium Development Goals, Pakistan recently embarked on an effort to collect data regarding crucial issues of human development, such as health, poverty, and education. For their effective use in policy formulation, however, governments need to find ways of making the data easily accessible. It is argued that Geographical Information Systems (GIS) can play a major role here. The data compiled by the Federal Bureau of Statistics at district level are used in this article to develop maps on child health in the province of Punjab. Correlation allows identification of major determinants of the health status of children. For Punjab, these appeared to be mother literacy, vaccination coverage, and the incidence of poverty. Interpolation (here using Inverse Distant Weighting) and variable aggregation allow for easy identification of areas of concern at sub-district level. For Punjab, the areas most affected by negative health conditions are in the southwest. It is argued that health disparities can be addressed more effectively with the help of the presented methods because they help to close the information gap in the health system and contribute toward more precise allocation of funds and infrastructure.

Keywords: statistical data, GIS, mapping, health disparities, Pakistan

\section{Zusammenfassung: Räumliche Muster von Kinder- gesundheit in der Provinz Punjab, Pakistan. Vorteile Geographischer Informationssysteme für die Datenanalyse}

Im Kontext der Millennium-Entwicklungsziele unternimmt Pakistan in den letzten Jahren Anstrengungen, statistische Daten bezüglich fundamentaler Bereiche der menschlichen Entwicklung, wie Gesundheit, Armut und Bildung, zu sammeln. Um für die Formulierung entsprechender Politiken nutzbar $\mathrm{zu}$ sein, müssen die verfügbaren Daten allerdings erschlossen werden. Der Artikel stellt die These auf, dass Geographische Informationssysteme (GIS) hier eine positive Rolle spielen können. Daten des Federal Bureau of Statistics auf Distriktebene werden im Folgenden verwendet, um Karten des Gesundheitsstatus von Kindern zu erstellen. Entscheidende Determinanten des Gesundheitsstatus werden anhand von Korrelationen ermittelt. Anschließend wird eine Karte mit einer Auflösung unterhalb der Distriktebene erstellt, indem eine aggregierte Variable mit Hilfe des Inverse Distant Weighting interpoliert wird. Die Ergebnisse 
zeigen, dass der Südwesten Punjabs besondere Probleme bezüglich des Gesundheitsstatus von Kindern aufweist. Gesundheit hängt dabei insbesondere von drei Variablen ab: der Bildung der Mütter, der Impfungs- und der Armutsrate. Die Interpolation ermöglicht, Problemgebiete unterhalb der Distriktebene auf einfache Art und Weise zu identifizieren. Da GIS einen Beitrag dazu leistet, das Informationsdefizit im Gesundheitssystem zu schließen, und Finanzen sowie Infrastruktur präziser zu allozieren, ist davon auszugehen, dass Disparitäten bezüglich des Gesundheitsstatus effektiver angegangen werden können, wenn die hier präsentierten Methoden angewandt werden.

Schlüsselwörter: statistische Daten, GIS, Kartendarstellung, Gesundheitsdisparitäten, Pakistan

\section{Résumé: Géographie des inégalités de santé infantile dans la province du Punjab (Pakistan). Les avanta- ges des Systèmes d'Information Géographique dans l'analyse des données}

Dans le cadre global des Objectifs du Millénaire pour le Développement, le Pakistan a récemment entrepris des efforts de collecte de données d'indices déterminants du développement humain, comme la santé, la pauvreté et l'éducation. Cependant, afin de pouvoir utiliser les données disponibles, les gouvernements doivent les rendre exploitables. Cet article soutient que les Systèmes d'Information Géographique (SIG) permettent d'atteindre cet objectif. Les données du Bureau fédéral de la statistique à l'échelle du district sont utilisées dans cet article pour dresser une carte de la santé infantile dans la province du Punjab. Les corrélations statistiques permettent d'identifier les variables déterminantes indiquant l'état de la santé. Par la suite, une variable composite est introduite pour dresser une carte à l'échelle inférieure au district en interpolant les résultats selon la méthode de la pondération inverse à la distance. Les résultats montrent que l'état de la santé infantile est le moins avancé dans le sud-ouest du Punjab. La santé dépend surtout de trois éléments: l'éducation des mères, l'immunisation des enfants et la prévalence de la pauvreté. L'interpolation permet d'identifier facilement les régions en difficulté à une échelle inférieure au district. En conclusion, les méthodes SIG permettent de répondre efficacement aux disparités en matière de santé infantile, grâce à leur capacité à combler les lacunes d'informations du système sanitaire et grâce à une allocation des fonds et des infrastructures plus précise.

Mots-clés: données statistiques, SIG, représentation cartographique, disparités de santé, Pakistan

Dipl--Geogr. Kashif Ur-Rehman, University of Basel, Institute of Geography, Urban and Regional Studies, Klingelbergstrasse 27, CH-4056 Basel, Switzerland.

e-mail: K.Ur-Rehman@unibas.ch

Dipl.-Geogr. Anna Zimmer, University of Bonn, Department of Geography, Meckenheimer Allee 166, D-53115 Bonn, Germany.

e-mail: zimmera@uni-bonn.de

\section{Manuskripteingang/received/manuscrit entré le} 2.12.2009

Annahme zum Druck/accepted for publication/accepté pour l'impression: 22.3.2010 